Aldo Oscar Valesini

\title{
LECTURA DE UN POEMA DE ALEDO LUIS MELONI $Y$ SUS VARIANTES
}

\section{LAS TUSCAS}

\author{
A veces vuelve \\ de la distancia \\ la memoria querida de las tuscas. \\ Las tuscas se cenían \\ a los caminos \\ con un amor humilde y para siempre; \\ en los atardeceres de hogueras encendidas \\ ellas abrían como un pebetero \\ el corazón enamorado. \\ Su aroma fuerte y áspero subła \\ entre la polvareda \\ que levantaban las volantas rusas. \\ La polvareda \\ se quedaba en el aire suspendida \\ como una niebla cálida, \\ y entre el aroma de las tuscas \\ uno escuchaba y comprendia \\ las voces misteriosas de la tierra. \\ in: Meloni, Aledo Luis, Poemas y Coplas, Resistencia, Moro \\ Hnos., 1980, p. 155.
}




\title{
LAS TUSCAS
}

\author{
A veces llega \\ de San Antonio \\ la memoria querida de las tuscas. \\ Las tuscas se abrazaban \\ a los caminos \\ con un amor humilde y para siempre. \\ En los atardeceres de hogueras encendidas \\ ellas abrían como un verde pebetero \\ el corazón enamorado. \\ Su aroma fuerte y áspera subía \\ entre la polvareda \\ que levantaban las volantas rusas. \\ La polvareda \\ se quedaba en el aire suspendida \\ como una niebla călida; \\ y entre el aroma de las tuscas \\ uno escuchaba y comprendía \\ las voces enigmáticas, en clave, de la tierra.
}

Meloni, Aledo Luis, Edición inédita.

La obra poética de Aledo Luis Meloni (maestro nacido en la provincia de Buenos Aires, radicado en el Chaco desde 1937) constituye, sin dudas, una de las más lúcidas y profundas indagaciones de la literatura regional, y por ende, un valioso aporte a la poesía nacional.

Tal vez su condición de escritor tardío (publica su primer libro a los 44 años) explique la notable uniformidad estilística y temática de su obra total.

Poética de la soledad y la melancolía, de la desnudez del hombre que sólo tiene a su disposición "la palabra desnuda" para intentar la aventura del descenso a las profundidades del ser.

Obra apoyada en un equilibrio perfecto entre la expresión mesurada y un hondo lirismo logrado sin desdoblamientos conceptuales inútiles a la sensibilidad, sino a través de la concen- 
tración del máximo poder expresivo en una imagen.

El poema "Las tuscas" pertenece a su sexto libro, La palabra desnuda" aparecido en 1980.

Nuestra labor consistirá en el análisis descriptivo de las imágenes para tratar de establecer con posterioridad, sus posibles connotaciones intencionales. Al mismo tiempo estableceremos la mecánica de una conciencia imaginante impulsada por dos corrientes paralelas que se materializan en la dialéctica de la espera.

El eje de la primera estrofa, y además, el ordenador semántico del poema está dado en el verbo "Llega".

Llegar supone un camino recorrido; una coexistencia de dos planos temporales: un presente (al producirse el hecho) y un pretérito (la acción que lo permite); una búsqueda del hogar cálido donde alguien, tal vez, espera.

Estructural y semánticamente, la llegada es definitiva. Aquí, el objeto del verbo constituye la materia esencial de la imagen: "La memoria querida de las tuscas".

Una vez instalado el recuerdo en ese presente inmóvil, ya no es necesario volver a nombrarlo.

¿Qué íntimo regocijo el de quien tiene la posibilidad de recibir una memoria querida! iEn qué profundidad del alma renacen las sensaciones, preparadas para conmoverla como la primera vez!.

Ya está seguro, a resguardo. El poeta ha tomado conciencia del lugar y del tiempo; nada le es extraño. ¿Por qué si no esa insistencia que lo llevó a precisar: "...de la distancia..." por "...de San Antonio..."? San Antonio fue el pequeño mundo rural donde vivió durante veinte años.

Nada mejor que convertir en palabra esa materia de ensueño que produce una claridad en la conciencia para alegría del corazón.

Ya no puede saborear, sosegadamente, la dicha de la compañía esperada. Meloni corrige en su segunda edición: "llega" en lugar de "vuelve". ¿Cuál es la diferencia y qué sentido puede haber entre ambos verbos? Si bien la raíz dinámica es parecida, ha quitado lo rutinario, reiterativo; ha querido rejuvenecer el hecho, eliminando la voz que dicta la costumbre para sugerir el asombro. Una llegada es más un espectáculo que una vuelta.

Esta presencia no tiene las características de un viajero errante, de aquellas que reposan momentáneamente en nuestro hogar sin que podamos saber su territorio de origen. Es una antigua conocida. Resulta agradable acoger a quien hemos visto nacer $y$ con quien hemos compartido fragmentos de un tiempo pasado. El alma se entrega con más confianza, y no nos atreve- 
mos a contradecirla. En su compañía callamos, entrecerramos los ojos, y vivimos, ya no "en...", sino "junto a...".

La espera tampoco es puntual: "A veces..." convierte al acontecimiento en espectáculo, en sorpresa; es el complemento de "llega". Un espectáculo deseado que posee un valor especial para el poeta: la calificación "querida" es definitoria de un plano esencial del poema: lo sentimental, lo evocado atrapado en la gota de un afecto que permanece intacto. De aquí en más, esta llegada traducirá la dialéctica de la espera:

- la imagen (el objeto que llega en la memoria)

- lo anímico (el sujeto que aguarda)

La llegada irá tomando posesión de su soledad de manera creciente hasta desnudar la intimidad del poeta. En este sentido, es una presencia devastadora. De aquí en más, los dos planos semánticos se entrecruzarán en un juego de misteriosos acoples, de potentes imágenes, de imprecisas fuerzas que pugnarán por dar la bienvenida a la memoria. El escritor "ya no pertenece al dominio magistral donde expresarse significa expresar la exactitud y la certeza de las cosas y de los valores según el sentido de sus límites". (1)

Las tuscas se constituirán en la presencia equidistante de dos macizos complejos semánticos, cuyas realidades diferentes ponen de manifiesto la mecánica de la estructuración del poema.

Acá, el mundo de los objetos aparece, tal como lo señala Dufrenne, en ese espacio creado a partir de la ruptura producida entre el sujeto pensante y el objeto pensado. La meditación se encarga de establecer los parámetros del silencio interior, distribuir en él, voluntariamente, a los recién llegados.

El recuerdo despliega su abanico gracias a la posibilidad latente en ese espacio virgen que el poeta ha dejado en si mismo. En el "tomar conciencia", que es más un abrir la puerta ante la inminencia del arribo, se ha producido, como en el teatro, el oscurecimiento de la sala; todo dispuesto para el espectáculo; el escenario es ese umbral casi imperceptible que lo separa del mundo presente, esa distancia esencial que le permite replegarse sobre sí.

Aqui, las leyes del ordenamiento de los objetos ignorarán las de la realidad; el creador (a través del dinamismo inconsciente) establece las relaciones; ¿y qué paradigma sino el expresado en el verso 3: "la memoria querida de las tuscas" regirá tal reconstrucción? Por su posicion central en el sintagma, es como la arteria por donde fluirán las voces, sus conceptos, los claroscuros anImicos apoyados en el imperfecto, que es siempre una voz melancolica, un lamento disimulado que mira hacia el pasado. 


\section{A: EL HOMBRE QUE ESPERA}

"El poema es mediacion: por gracia suya, el tiempo original, padre de los tiempos, encarna en un instante. La sucesión se convierte en presente puro, manantial que se alimenta a sí mismo y trasmuta al hombre. La lectura del poema ostenta una gran semejanza con la creación poética. El poeta crea imágenes, poemas; y el poema hace del lector imagen, poesła". (2) ¿Cómo sustraernos, cómo ignorar el amor, fundamento de toda la composición?

Ferdinand de Saussure (3) habla de dos tipos de relaciones posibles entre los signos: sintagmáticas y asociativas. La primera, de carácter lineal, se establece mediante la oposición de los términos presentes en el discurso; mas "fuera del discurso, las palabras que ofrecen algo en comán se asocian en la memoria y así se forman grupos en el seno de los cuales reinan relaciones muy diversas..." que, en general, denominamos el campo asociativo.

Este conjunto de componentes, que existen virtualmente "in absentia", en calidad de correferentes, según Umberto Eco, es lo que se conoce como "campo semántico". Hay una constelación de palabras que reclaman, con mayor o menor razón, su filiación de parentesco con una central.

iQué despliegue sensitivo el del poeta, capaz de desdoblar, prolongar y rejuvenecer el primitivo indicador, "querida"!

Una notable corrección diferencia las dos versiones en el verso 4: "Las tuscas se ceñían..." / "Las tuscas se abrazaban...". Luego, en la misma estrofa, completa la idea: "con un amor humilde y para siempre".

Lo que ingenuamente calificaríamos de simple redundancia, es la transferencia acabada, total, clara, de su estado. "...la fusión -o mejor: la reunión- de la palabra y la cosa, el nombre y lo nombrado, exige la previa reconciliación del hombre consigo mismo y con el mundo", dice Octavio Paz (4). No podemos concebir otra forma de encuentro de mayor densidad espiritual que el amor. El "corazón enamorado", territorio expandido hacia la luz, hacia la sombra; compartido por los claroscuros, presto a temblar frente al mínimo roce de la brisa, donde ha construído una sala habitada por los rebeldes seres de la memoria

¿Hay una forma de esperar al ser querido que no nos obligue a adoptar esa actitud de apertura, exterior o interior?

La espera es la búsqueda de algo que pueda desplazar una ausencia. Alli no hay objetos, es un territorio despoblado. Solamente una atmosfera que rodea al poeta, se expande desde su intimidad, traspasa su piel y dilata el instante. 
$Y$ nos sentimos conmovidos al introducirnos en el reino creado por las imágenes que indican la transferencia de dos cosmos tan distantes en el tiempo, pero tan contiguos gracias a la dinámica impuesta por la emoción. ¿Que observa, qué capta un hombre en la presencia del ser querido, sino el aroma, como una cualidad sustancial del aire.?

La cuarta y la quinta estrofas expresan la relación lineal "aroma" - "polvareda" - "niebla cálida".

Dejemos de lado el conector "polvareda", cuya naturaleza, si bien puede estar teñida de cierto animismo, se debe a la coacción de los vocablos que lo rodean, y no a sus propiedades intrínsecas de imagen. Bástenos con su función de establecer el parentesco semántico entre los restantes términos de la tríada.

"Segán la teoría 'contextual' o 'funcional' de la significación, (...) el sentido de una palabra consiste en el conjunto de los contextos de que puede formar parte" (5). Es altamente esclarecedora la posición de "aroma" en esta constelación de imágenes anímicas, como un complemento de "niebla cálida", que en el ensueño de perfiles difusos asume su valor emocional gracias a la sinestesia concretada en el adjetivo.

Esta solidaridad semántica entre unidades de la lengua a las que el código no les asigna normalmente tales áreas de significación, producen, como lo afirma Umberto Eco, "una crisis en el lenguaje" (6). Nos recuerda también a la tesis de Charles Sanders Peirce: "El valor del símbolo, y especialmente del símbolo lingüístico consiste en que nos da la posibilidad de predecir el porvenir. La palabra y el futuro están indisolublemente unidas" (7).

$Y$ en este espacio, donde el alma se halla acorralada entre estímulos que agudizan su estado de serenidad y de gracia, de repente surge el sonido. "Las voces misteriosas" representan el áltimo bastión, el más costoso, y en consecuencia, el más codiciado que la memoria ha traído hasta el poeta.

¿Podremos, en realidad, encontrar otra actitud más conveniente al ser enamorado?. La atención absoluta, el deseo de atrapar en su totalidad las mínimas partículas de lo amado, y ese intento, muchas veces vano aunque insaciable, de comprenderlo.

La actitud es la misma, el objeto ha variado sensiblemente de sustancia, mas no podemos negar que en ese instante, está "escuchando y comprendiendo" las voces de ese recuerdo con el que puede compartir, al fin, su soledad. 


\section{B: LO ESPERADO A TRAVES DE LA IMAGEN}

"Primeramente el objeto no es real, sino un buen conductor de lo real", observa Benjamín Fondane. Gastón Bachelard completa la idea: "El objeto poético, debidamente dinamizado por un nombre pletórico de ecos, será, según nosotros, un buen conductor del psiquismo imaginante. Para esta conduccion hay que llamar al objeto poético por su nombre, su viejo nombre, dándole su justo número sonoro, rodeándolo de los resonadores a los que va a hacer hablar, de los adjetivos que prolongarán su cadencia, su vida temporal" (8). Repetimos en silencio (pues la palabra cautiva adquiere una dimensión diferente de la dicha en alta voz): "la memoria querida de las tuscas".

El dinamismo de la imagen poética nos remite a un espacio infinito, un espacio informe donde irá estableciendo los parámetros que definen el espectáculo total de la imaginación: en primer lugar, la coordenada espacial: "...se abrazaban/ a los caminos/...", y en seguida, la de tiempo: "En los atardeceres...". Aquello que no nos resignamos a olvidar, tiende a preservarse más bien de una manera que de otra (aquí parafraseamos a los gestaltistas). El inconsciente regala a la imaginación un instante del objeto, un pantallazo que ha rescatado de la multitud, y lo sostiene para siempre.

Es suficiente para generar la emoción poética. iQué poco necesita la ansiedad de la poesía para saciarse, pero qué profundamente debe descender para encontrar el filón donde abrevarse!.

Inmediatamente la imagen establece el parámetro subjetivo, la valoración del objeto, que se diseminará en una serie de elementos que comparten una misma veta de materia imaginada, gracias a las reiteraciones, analogías y sinonimias: "Su aroma fuerte y áspero subía/ entre la polvareda/ que levantaban las volantas rusas./La polvareda/ se quedaba en el aire suspendida/ como una niebla cálida".

Los dos sujetos, "aroma" y "polvareda", están calificando según la brajula íntima del poeta la imagen primitiva de las tuscas. Antes hablamos del peso emotivo de "aroma", lo cual nos exime de comentar este aspecto.

¿Cómo no prestar atención al dinamismo expresado en las imágenes de cada estrofa? El aroma, elemento existente en el umbral que separa el mundo objetivo del subjetivo, es quien posee el don del movimiento; pero no un movimiento horizontal, homogéneo, sino un movimiento de ascenso. ¿Tal vez el alma del poeta también asciende en busca del perfume que necesita el recuerdo rescatado?. 
Por otro lado, las tuscas también tienen su fondo de quietud, de morosa detención que las convierte en un ser mixto: (quieto como objeto recordado), ascendente (en la medida en que puede escapar al estatismo del pasado y llegar hasta el presente). Creemos que aquel recuerdo que emerge de la masa informe de la memoria cumple un movimiento hacia arriba, de florecimiento, de triunfo. Jamás imaginaríamos horizontal la trayectoria del objeto de la evocacion.

"La polvareda/ se quedaba en el aire suspendida/ como una niebla cálida". Esta comunión de la polvareda con el aire nos parece, aunque obvia, necesaria, permanente, casi eterna; una pareja cuya alianza establece el espacio y el tiempo donde habitan las tuscas.

El aroma, sujeto de la kinestesia, reaparece en la altima estrofa, como un contexto necesario de la imagen final: "...uno escuchaba y comprendía/ las voces enigmáticas, en clave, de la tierra".

No había sido vana la calificación anterior. Al contrario, a través de la cualidad es posible acceder a la imagen esencial del poema. "Yo soy un hombre de la tierra", diră el autor.

iCon qué especial intensidad habrá que captar ese sonido que retorna y llega a el sin obstáculos! iCómo sobrecoge al espiritu escuchar las voces queridas, escucharlas en su dialecto, que sólo nosotros conocemos, al que sólo nosotros somos capaces de otorgarle un sentido!.

\section{C: EL FIN DE LA BUSQUEDA}

Hasta ahora hablamos de la actitud del poeta: la espera; creemos haberla analizado en el despliegue de las imágenes sensitivas comentadas en (A). Luego, tratamos de reconstruir el objeto esperado (B), orientados por Gastón Bachelard: "El hombre de la ensoñación y el mundo de su ensoñación están muy proximos, se tocan, se compenetran " (9). En ambos analisis se ha superpuesto la imagen: "...las voces enigmáticas, en clave, de la tierra". Aquí, creemos, concluye la búsqueda presente en todo el poema. "La palabra es un puente mediante el cual el hombre trata de salvar la distancia que lo separa de la realidad exterior" (10). Aqui encontramos esta búsqueda, expresada en dos planos: el del lenguaje y el de la vivencia.

¿No era el dialogo con la tierra lo que el poeta persiguio, imagen tras imagen? ¿No es aquí, acaso, donde deja caer el punto final, para tener, al fin, la posibilidad de escuchar en silencio esas voces secretas que la memoria le ha trafdo?. 
Nos atrevemos a hablar de un metalenguaje, pensando que estas voces han sido los impulsos, el tendal de vigilias que fue recogiendo la palabra, para dar la bienvenida al recuerdo, y celebrar con él ese banquete, donde se habla "en clave", y donde las palabras, como todo lenguaje poético, son "misteriosas", o, como lo dijo en su edición corregida, "enigmáticas". 
NOTAS

(1) Blanchot, Maurice, El espacio literario, p. 20.

(2) Paz, Octavio, El Arco y la Lira, p. 25.

(3) Saussure, Ferdinand, Curso de Lingüística General, caps. V - VI.

(4) Paz, Octavio, op. cit., p. 37.

(5) Cohen, Jean, La estructura de la obra literaria, p. 110.

(6) Eco, Umberto, Obra abierta, p. 150.

(7) Jakobson, Roman, Lingüística, Poética, Tiempo, p. 97.

(8) Bachelard, Gastón, El aire y los sueños, p. 14.

(9) Bachelard, Gastón, La poética de la ensoñación, p. 238.

(10) Paz, Octavio, op. cit., p. 36. 


\section{BIBLIOGRAFIA}

Bachelard, Gastón, El aire y los sueños, México, F.C.E., 1980.

La poética de la ensoñación, México, F.C.E. 1982.

$\frac{\text { La poética del espacio, México, F.C.E., }}{1983 .}$

El agua y los sueños, México, F.C.E., 1978.

Barthes, Roland y otros, Análisis Estructural del Relato, Serie Comunicaciones, Barcelona, Ediciones Buenos Aires S.A., 1982.

Blanchot, Maurice, El espacio literario, Bs. As., Paidós, 1969.

Cohen, Jean, La estructura de la obra literaria, Madrid, Gredos, 1977.

Eco, Umberto, Obra abierta, Barcelona, Ariel, 1979.

Giraud, Pierre, "El campo estilístico del "abismo" de Baudelaire, in: Tres enfoques de la literatura, Bs. As., Centro Editor de América Latina, 1971.

Jakobson, Roman, LingüIstica, Poética, Tiempo, Conversaciones con Krystina Pomorska, Barcelona, Crítica, 1981.

Meloni, Aledo Luis, Poemas y Coplas, Resistencia, Moro, 1980.

Paz, Octavio, El arco y la lira, México, F.C.E., 1983.

Veiravé, Alfredo, Juan L. Ortiz, Buenos Aires, Carlos Lohle, 1984. 